\title{
PENSANDO A CONSTRUÇÃO DA IDENTIDADE HOMOERÓTICA EM ANATOMIA DA NOITE DE MÁRCIO EL-JAICK
}

\section{THINKING ABOUT THE CONSTRUCTION OF HOMOEROTIC IDENTITY IN ANATOMIA DA NOITE BY MÁRCIO EL-JAICK}

\author{
Izaías Serafim de Lima Neto ${ }^{1}$ \\ Auríbio Farias Conceição ${ }^{2}$ \\ Francisco Vieira da Silva ${ }^{3}$
}

Recebido em: 19 ago. 2018

Aceito em: 23 nov. 2018

DOI 10.26512/aguaviva.v3i3.22270

RESUMO: O presente estudo objetiva analisar a identidade homoerótica na obra Anatomia da Noite (2009) de Márcio El-Jaick. Essa análise se debruçará sobre o personagem-narrador Henrique, sujeito de meia idade, homossexual, que experiencia o decorrer de uma noite na capital paulistana e descreve as sensações diversas e ambientes possíveis nos becos e baladas LGBT. Para tanto, nos utilizamos dos estudos de Bauman $(2004 ; 2005)$ e suas contribuições para a compreensão da identidade no período pós-moderno, bem como Hall (2005) e suas teorias sobre o traçado histórico da identidade e constituição do sujeito. Ainda, Trevisan (1995) contribui ao estudo por apresentar um tratado sociológico no qual desvela as diversas imagens sociais construídas sobre os sujeitos homossexuais no Brasil desde o período colonial. Além desses autores como Foucault $(1995 ; 2015)$ e Rose (2001) contribuíram diretamente com suas noções de identidade e subjetificação. As análises permitem perceber que a identidade homoerótica de Henrique se revela através de uma experiência do sexo e da sexualidade como forma de escape de uma solidão profunda atrelada a diversas mazelas psicológicas resultadas de conflitos internos e externos do personagem.

Palavras-chave: Identidade; Homoerotismo; Literatura Contemporânea.

\footnotetext{
${ }^{1}$ Graduado em Letras com habilitação em Língua Portuguesa pela Universidade Estadual da Paraíba (UEPB). Mestrando do Programa de Pós-Graduação em Letras (PPGL) da Universidade do Estado do Rio Grande do Norte (UERN). E-mail: izaiasserafimneto@outlook.com

${ }^{2}$ Doutor em Literatura e Interculturalidade pela UEPB. Professor da Universidade Estadual da Paraíba (UEPB) no campus de Catolé do Rocha/PB. E-mail: auribiofarias@ yahoo.com.br

${ }^{3}$ Doutor em Linguística pela Universidade Federal da Paraíba (UFPB). Professor da Universidade Federal Rural do Semi-Árido (UFERSA), campus de Caraúbas/RN e do Programa de Pós-Graduação em Letras (PPGL) da Universidade do Estado do Rio Grande do Norte (UERN) e do Programa de Pós-Graduação em Ensino (POSENSINO) da Associação entre a UERN, UFERSA e o Instituto Federal de Educação, Ciência e Tecnologia do Rio Grande do Norte (IFRN). E-mail: francisco.vieiras@ufersa.edu.br
} 


\begin{abstract}
The present study has as main objective to analyze the homoerotic identity in the book Anatomia da noite (2009) by Márcio El-Jaick. This analysis will focus on the character-narrator Henrique, middle-aged, homosexual subject who experiences a night in the capital of São Paulo and describes the differents sensations and possible environments in the LGBT alleys and ballads. To do so, we use Bauman (2004; 2005) studies and his contributions to the understanding of identity in the postmodern period, as well as Hall (2005) and his theories on the historical tracing of the identity and constitution of the subject. In addition, Trevisan (1995) contributes to the study by presenting a sociological treatise in which he unveils the various social images constructed on homosexual subjects in Brazil since the colonial period. In addition, authors such as Foucault $(1995 ; 2015)$ and Rose $(2001)$ contributed directly to their notions of identity and subjectification. After the analysis of the narrative, we suggest that Henrique's homoerotic identity is revealed through an experience of sex and sexuality as a way of escape from a deep solitude coupled with various psychological problems resulting from internal and external conflicts of the character.
\end{abstract}

Keywords: Identity; Homoerotic; Contemporary Literature.

\title{
INTRODUÇÃO
}

A homossexualidade permanece no rol dos tabus sexuais da sociedade ocidental. Independentemente das mudanças culturais ocorridas nos últimos 60 anos, tanto no Brasil quanto no resto mundo, uma literatura homossexual ainda é tímida e desconhecida da população leitora de literatura. Isso se deve, provavelmente, ao seguinte fato: o cânone literário silenciou por muito tempo as obras que incidiam nesta temática (afora Adolfo Caminha e obras de Caio Fernando Abreu, poucas são as obras literárias conhecidas do grande público que empreendam personagens homossexuais e suas diversas vivências humanas.).

Esta marginalização tende a ruir durante a produção literária modernista e ganha mais força na contemporaneidade. Entretanto, essa força, se comparada às demais denominações de produção literária (regionalista, urbana, policial, infantil, etc) é ínfima. Desta maneira, é de suma importância que se viabilize estudar literatura nomeada homossexual/homoerótica (ou LGBTQ), para que se perceba que esses sujeitos não podem mais estar à margem do protagonismo literário, sendo o tempo de centralizá-los.

Os estudos culturais aliados a outros campos dos conhecimentos humanos são, certamente, a mola propulsora para que se ouse questionar uma produção literária homossexual à luz da crítica literária. Esta crítica que sempre lidou com homens, brancos, heterossexuais, 
em contrastes de caráter, fé, economia e loucura, que pouco se debruçaram sobre o espaço intermediário das identidades. Esses estudos, a seu modo, escancaram as portas da literatura para que as vozes homossexuais sejam mais explícitas e não se resguardem no "quase acontecido" de Frederico Paciência de Mário de Andrade, bem como no subentendido de Aqueles dois de Caio Fernando Abreu.

Este espaço agora aberto é solidificável pela pesquisa científica que não permitirá que se calem estas vozes. Neste sentido, trazer à tona na academia estudos que deem conta de olhar o que esteve à margem na literatura, a fim de enfocá-los ao lado dos clássicos é de suma importância porque reconhece, ao passo que a literatura, os próprios sujeitos que a produzem e são tematizados nela.

Diante disso, pretendemos no presente estudo analisar, tomando por base as teorias de identidade e identificação, erotismo e sexualidade, a obra literária Anatomia da noite do escritor brasileiro Márcio El-Jaick publicada em 2009 pela editora Edições GLS. Nessa obra, intentamos investigar quais traços identitários constituem o personagem-narrador Henrique, traçado dentro da narrativa como sujeito homossexual de vivência desregrada, em meio a vícios como cigarro, bebida, drogas, etc., o qual experimenta e reverbera uma noite na cidade grande e suas diversas formas anatômicas que vão dos sujeitos aglomerados numa balada gay a sarjeta fria e suja.

Neste sentido, nosso objeto de pesquisa tem seu contexto de produção no Brasil no início do Século XXI. Márcio El-Jaick é jornalista, formado pela PUC-Rio, e publica, desde o fim década de 1990, textos literários enquadrados nas temáticas GLS/LGBTQ. As principais obras do autor são a coletânea de contos Era uma vez... os contos gays a carochinha (2001), os romances Matéria básica (2007), No presente (2008) e Anatomia da noite (2009), todas publicadas pela editora Edições GLS.

Sua notoriedade dentre os autores que tratam do homoerotismo e da homoafetividade se deu excepcionalmente em 1999 quando foi um dos vencedores do III Festival Literário Xerox - Livro Aberto com a novela $E$ tudo mais são sombras. No cerne de sua produção, há areincidência da representação de sujeitos homossexuais interpelados pelas diversas possibilidades da vida, o que conglomera desde os sentimentos e as experiências positivas a toda a carga de negatividade que a modernidade lança sobre os homens.

Faz-se necessário situar o espaço da produção de El-Jaick no panorama das produções literárias contemporâneas, as quais, segundo Resende (2008), caracterizam-se por trazerem à 
tona temáticas, sujeitos e experiências presentes do homem pós-moderno, abandonando em sua constituição central os idealismos de nacionalidade, amor e estética. Nessas produções, segundo a autora, mesclam-se os diversos gêneros em hibridismo, as diversas ideologias se contornando, as diversas formas e formatações da linguagem (culta, coloquial, cibernética) para findar numa literatura que se pauta na experimentação.

Dito isso, e voltando a tratar sobre o conceito de sujeito, é possível afirmar que o homem enquanto sujeito social exerce, sobre si e sobre os outros, forças de reconhecimento e conhecimento que objetificam-no e subjetificam à mesma medida. Esse "mecanismo" é conhecido como identidade, identificação e também diferenciação. Entendeu-se, por muito tempo, que identificar-se seria compreender a unicidade do eu e sua homogeneidade diante da sociedade.

No entanto, estudos na sociologia, filosofia e literatura têm desmistificado tal assertiva colocando em voga a ideia de heterogeneidade do sujeito, o que, por sua vez, não permite mais se falar em identidade (no singular) e exige-se que se discuta, analise e perceba as identidades com as quais os indivíduos se identificam num processo de mudança contínua, tendo em vista a efervescente sociedade em que vivemos.

Neste sentido, atentar-se a um sujeito como o homossexual (observando-se de maneira crítica a história da homossexualidade, os estigmas e discursos em torno da identificação desses sujeitos) é de suma importância, pois se faz ouvir a voz que deles ecoa e que há muito vem sendo submetida. Ainda, desvelar essa voz na literatura, enquanto espaço de criação humana e de mimese da vida real, é realinhar a humanidade desses sujeitos com uma das mais exímias artes do homem: a literária.

Por muito tempo, esses sujeitos foram submetidos ao silêncio em todas as esferas da vida humana. Sua existência era negada (ou pelo menos se impunha o estigma de que suas identidades não eram concordantes com a hegemonia social vigente) inclusive na literatura, pois, ao tratarmos da literatura brasileira, o homossexual aparece raríssimas vezes nos textos literários.

A tematização da vida dos homossexuais ganha força na literatura apenas em meados da década de 1960 com os movimentos de estudos culturais e de discussão de gênero. Neste sentido, é essencial se pensar agora na vida humana do homossexual captada pelo olhar da literatura, pela estética e pela inerente relação social que a ficção tem com a realidade. 
Por isso, questionamos neste trabalho: como se constitui identitariamente o sujeito homossexual representado em Anatomia da noite de Márcio El-Jaick? Quais traços sociais, psicológicos e de identificação o personagem-narrador Henrique apresenta? Diante dessas indagações, compreendemos que ao analisarmos uma obra literária que tematiza a vida de um homossexual e suas mais diversas vivências contribuímos para que a academia e a sociedade observem e desmistifiquem ideários previamente construídos em nossa história, a maioria atrelados ao preconceito.

Enfim, as possibilidades teóricas no campo da literatura de temática homoerótica nos abrem os olhos para os seguintes pontos: é necessário se pensar a homossexualidade e a construção social dessa identidade; a literatura não é ilesa diante desse processo; o cânone literário por muito silenciou as "vozes homossexuais" em sua teia de produção de arte; a contemporaneidade abriu brechas para que se faça literatura homossexual e que a mesma ocupe espaço da produção humana que deve ser prezado e estudado; é de suma importância veicular produções científicas nesse sentido para que se quebre cada vez mais as barreiras impostas a esses sujeitos que, em sua maioria, são postos sob um véu de inexistência por não obterem lugar nos diversos campos da sociedade.

\section{Identidade, identificação e diferenciação}

Identidade pode ser considerada de várias formas, tanto pelo termo e sua carga semântico-gramatical, quanto pelo conceito que se estabeleceu sobre a "coisa" identidade na história do pensamento sociológico e filosófico da humanidade. No que diz respeito ao funcionamento dicionarizado do termo, identidade passeia desde documento oficial que designa, seleciona e individualiza a pessoa até uma formulação autoafirmativa e de reconhecimento pessoal. A “coisa” identidade, por seu turno, é atravessada por uma gama de fatores sociais e estatísticos que a empreendem como resultado de uma nacionalidade, de um grupo social, de uma casta hierárquica, de um domínio de conhecimento ou área de sabedoria da qual o humano (individualizado) se apropria e toma para si como se fora a sua "face" exposta aos demais humanos, também individuais.

Nesse sentido, alguns estudiosos se debruçaram a questionar e anatomizar a identidade compreendendo-a na história da humanidade como sendo construída e não como algo de natureza essencialmente humana, como que sendo vital. De acordo com Rose (2001), é possível 
perceber que o "eu" individualizado (enquanto ideia) tem estado sob estado de crise na modernidade. O autor propõe que há uma gama numerosa de filósofos e sociólogos que assinam o obituário do sujeito universalizado, individual e interior em si. Considera, ainda, que "os humanos nunca existiram, nunca puderam existir, nessa forma coerente, unificada - a ontologia humana é necessariamente a ontologia de uma criatura despedaçada no seu próprio núcleo" (ROSE, 2001, p. 139).

Neste sentido, o homem que é identificável (no sentido de que é plausível de identidade) não pode estar na ótica da homogeneidade, pois se converteu em uma criatura que se separa em si, se expande e reformula à medida que vive heterogeneamente. Uma visão de identidade enquanto algo predisposto à individualização não se sustenta, tendo em vista que o sujeito homem (a criatura, segundo Rose (2001) é resultado de processos amplos de cultura e discurso, ambos muito plurais. Ao fazer alusão à teoria deleuziana e gattariana, Rose (2001, p. 142) propõe que "os humanos [...] são mais múltiplos, mais transientes e mais não-subjetivados do que somos levados a acreditar".

Houve, diante desse contexto de conceitualização, uma quebra na concepção das identidades, dos sujeitos-eus. Hall (2005) apresenta um traçado histórico que atesta essas quebras: as mudanças do pensamento durante a Reforma e o movimento Protestante em primeira instância, seguidas pelo Humanismo Renascentista que "destituíram” a Igreja e emanciparam a consciência individual das instituições religiosas à época; em seguida, as revoluções científicas que outorgaram ao humano a habilidade e poder de investigar a natureza das coisas ao seu redor e a sua, movimento este atrelado ainda ao Iluminismo que alicerça a imagem do homem racional, libertado do dogma e investigador da totalidade do ser humano.

Ainda, para Hall (2005, p. 38)

[...] a identidade é realmente algo formado, ao longo do tempo, através de processos inconscientes, e não algo inato, existente na consciência no momento do nascimento. Existe sempre algo "imaginário" ou fantasiado sobre sua unidade. Ela permanece sempre incompleta, está sempre "em processo", sempre "sendo formada".

Diante disso, trataremos de identidade e identificação como processos inacabados do sujeito que o contornam e o modificam ao passo que o mesmo se diferencia dos demais outros 
sujeitos. Lidamos com esse conceito compreendendo-o dentro da esfera social que subjetifica o homossexual a partir da sua diferenciação com o heterossexual e demais condições sexuais.

Diante disso, refletindo sobre o sentido da subjetivação, Rose (2001, p. 143) aponta que

A subjetivação é [...] o nome que se pode dar aos efeitos de composição e da recomposição de forças, práticas e relações que tentam transformar - ou operam para transformar - o ser humano em variadas formas de sujeito, em seres capazes de tomar a si próprios como sujeitos de suas próprias práticas e das práticas de outros sobre eles.

Assim, é possível inferir que "tornar-se sujeito" pelo processo de subjetivação é antes de tudo um ato de consciência sobre si e sobre os outros. Esta formulação de si implica na concretização de uma identidade. Essa questão é vista, nesse sentido, com olhar de naturalização, isto é, identificar-se toma entornos de essencialidade na nossa sociedade ao passo que para isto é impreterível diferenciar-se. Silva (2013) tece considerações sobre a produção social da identidade e da diferença e aponta ambas categorias íntimas que não se desligam e se retroalimentam.

Silva (2013) esclarece que a identidade é produzida pelo processo de diferenciação, pois suas inferências apontam para a diferença como sendo o fator inicial nesta relação de interdependências. Pode-se, assim, sugerir que naquilo que nos diferenciamos alicerçamos os pontos nos quais no identificamos. São, pois, ambas as "coisas" produções da sociedade, aqui concebida na perspectiva de Bauman (2005, p. 24) para o qual "sociedade" "é entendida como maior totalidade coabitação humana”.

Corroborando essa questão, Silva (2013, p. 76) esclarece que

A identidade e a diferença têm de ser ativamente produzidas. Elas não são criaturas do mundo natural ou de um mundo transcendental, mas do mundo cultural e social. Somos nós que as fabricamos, no contexto das relações culturais e sociais. A identidade e diferença são criações sociais e culturais.

Outrossim, se retomarmos a ideia desmistificada por Rose (2001) de sujeito individual e plenamente homogêneo, é possível inferir que, neste processo de produção cultural e social múltiplo dos detalhes das identidades, o sujeito se atravessa a si mesmo e é atravessado pelos 
outros. Nesse processo extremamente amplo de sociabilidade, o sujeito é produzido "[...] como um agenciamento" clivado em várias relações e ligações “[...] que fazem emergir todos os fenômenos por meio dos quais, em seus próprios tempos, os humanos se relacionam consigo próprios [...]" (SILVA, 2013, p. 146).

Nesse sentido, os sujeitos produzidos nessas relações de conhecimento estão postos “[...] como eus desejantes, como eus sexuados, como eus trabalhadores, como eus pensantes, como eus intencionais - como eus capazes de agir como sujeitos" (SILVA, 2013, p. 146). Assim, projeta-se, possivelmente, a instância do eu como raiz do sujeito, isto é, o processo de individualizar-se é propulsor do de subjetivar-se.

Corroborando este pensamento, Hall (2005, p. 39) afirma que

[...] em vez de falar de identidade como coisa acabada, deveríamos falar de identificação, e vê-la como um processo em andamento. A identidade surge não tanto da plenitude da identidade que já está dentro de nós como indivíduos, mas de uma falta de inteireza que é "preenchida" a partir do nosso exterior, pelas formas através das quais nós imaginamos ser vistos por outros. ( rifos do autor).

Como propõe o autor, é possível inferir que no processo de identificação de nós mesmos existe insistente presença do olhar de um outro que, como vimos, é parâmetro também de diferenciação. À medida, pois, que não sou outro, não visto ou habito como outrem, sou eu, concretizo o que sou. Em vistas disso, o sujeito dividido se confirma, pois, as formas de diferenciação são tão amplas e complexas que as formas de identidades são tão plurais quanto: há sempre a identidade das vontades, da sexualidade, da produtividade, do pensamento, etc.

Nessa perspectiva, Foucault (1995, p. 231) afirma que "O sujeito é dividido em seu interior e em relação com aos outros. Este processo o objetiva". Neste sentido é possível afirmar que a identidade de qualquer sujeito principia na sua relação interna, uma espécie de constituição do conhecimento de si. A construção do homem passa, pois, por instâncias diversas, no âmbito social, econômico, individual, político, artístico, etc. Assim, constitui-se o processo de identificação de vários modos, através dos quais o homem conhece a si pela perspectiva do outro e se autoformula enquanto indivíduo maleável e em processo de formação identitária. 


\section{Da anatomia do erotismo no espaço íntimo da casa}

De acordo com a crítica contemporânea, poderíamos dizer que Anatomia da noite (2009) é um romance contemporâneo. Para Resende (2008, p. 20), por exemplo, no que diz respeito à narrativa contemporânea, existe uma

[...] apropriação irônica, debochada mesmo, em alguns casos, dos ícones de consumo; irreverência diante do politicamente correto; a violência explicita despida do charme hollywoodiano; a dicção bastante pessoalizada, voltada para o cotidiano privado; a memória individual traumatizada, seja por momentos anteriores da vida nacional, seja pela vida particular; a arrogância de uma juventude excessiva; a maturidade altamente intelectualizada; a escrita saída da experiência acadêmica e assim por diante [...].

E esses traços, em sua maioria, podem ser identificados na narrativa de Anatomia da noite (2009): 1- há uma referência à indústria pornográfica homoerótica na obra, bem como a marcas de vestimenta que simbolizam o mercado pop vigente na sociedade representada na narrativa e isso situa um tom de possível crítica ao consumismo; 2 - os trejeitos e diálogos dos personagens na obra, os quais são permeados por gírias (bicha, viado, bofe, urso, barbie), acenam para uma pessoalização do linguajar expressa pela autora como característica do texto literário contemporâneo; 3 - as memórias traumáticas de Henrique apresentadas no texto (tanto na relação com seu pai, quanto nas relações amorosas e sexuais) também aludem ao que a Resende (2008) concebe ser um ponto essencial na construção do narrador-personagem contemporâneo.

Habitualmente, em sua vida cotidiana, Henrique se deleita a ver revistas e filmes pornográficos e isso é hábito. Tal convívio o faz conhecer um número considerável de profissionais da área, bem como concebê-los "seres evoluídos”, pois, "[...] com seu corpo aerodinâmico, seu sexo avantajado, sua vida de viagens transatlânticas e festas varando a noite" (EL-JAICK, 2009, p. 08) eles são a expressão máxima de desinibição, do proveito da vida pela vida, sem preocupações ou limites do pudor. Henrique ainda os concebe "[...] verdadeiras fontes de inspiração, em busca sem limites pelo prazer, seu hedonismo irrevogável” (EL-JAICK, 2009, p. 08), ou seja, estes profissionais que viabilizam o sexo exposto em vídeos, filmes e redes sociais transcrevem a liberdade do prazer nos limites das relações pueris; entretanto, nessa adoração aos sujeitos que produzem mídias pornográficas, Henrique mostra-se em sua solidão 
mais nítida tendo em vista que busca o prazer em sua maioria de vezes no recôndito de sua casa, na masturbação, na admiração do ato sexual alheio como que sendo seu. Bauman (2004) abre margem às discussões que nos fazem pensar a solidão como reflexo da extrema liquidez das relações na nossa modernidade. Logo, este aspecto que se refere ao observar o sexo como que a uma outra cena artística quase desnudando seu tom erótico, levando-o ao cotidianismo, revela como se tem mudado as perspectivas em torno do que antes era tão secreto e beirava o profano (FOUCAULT, 2015).

A erotização da observação do sexo mostra que Henrique exime-se de relacionar-se ou o faz, como nos filmes pornográficos, ao acaso. Por outro lado, o personagem interpreta os filmes com dois posicionamentos distintos: “[...] dependendo do estado de espírito de quem vê, transformam-se em comédias inigualáveis” (EL-JAICK, 2009, p. 09). Observamos que ele relaciona a pornografia e seu efeito ao estado de espírito e humor de quem a consome enquanto entretenimento. Ele mesmo, por exemplo, mostra-se apático diante das cenas que, ao mesmo tempo em que revelam sua solidão, desvelam seu tédio e monotonia diante do sexo, que é vivido como uma forma de necessidade biológica e não saciedade emocional. Este fato atrela-se a outro: Henrique não se gosta em seu estado físico e psicológico atual. A monotonia da sua vida atravessa e impregna as pontas deste asterisco cronológico, ou seja, o sujeito elaborado por ElJaick (2009, p. 09) enfrenta a crise de si, o momento de não estar “[...] nos meus melhores dias [...]", entretanto esta consideração é comum, recorrente frente ao espelho, pois “[...] é o que ele sempre diz quando estou prestes a sair [...]” (EL-JAICK, 2009, p. 09).

De acordo com Hall (2005), a pós-modernidade trouxe ao sujeito uma relação consigo mesmo de autoanálise, de auto sujeição e de reconhecimento. O princípio desse conhecimento de si estaria fundado no fato de que é cada dia mais imprescindível sondar a sua própria intimidade, seus limites de ação e pudor a fim de regrar, conhecer, manter domínio sobre a sua própria vida. É no conhecimento de si que o homem individualiza-se e torna-se capaz de mover sua existência em meio a tantos outros milhares de existências.

. Assim, além de solitário, imerso em monotonia e tédio (característica do sujeito pósmoderno que, mesmo em meio à globalização das relações, permeia sua existência de enclausuramentos e solidões diversas), Henrique desvela-se na narrativa como que estando em combate com os julgamentos que a sociedade contemporânea suscita. Para enfatizar essa afirmação, recorremos ao que Henrique conclui em momento de reflexão: "Nós nos debatemos com o que somos" (EL-JAICK, 2009, p. 14), isto é, a consciência do personagem o faz perceber- 
se em constante conflito com o que é, pois em meio à monotonia da contemporaneidade (BAUMAN, 2004) ${ }^{4}$ o ser não se consegue manter quieto, em estático, mas vive debatendo-se nas suas vicissitudes, depressões, inquietações, males, sofrimentos e decepções.

Em seu interior, Henrique apresenta conflitos que o fazem sentir sua identidade de modo múltiplo. Ao observar o seguinte trecho, um poema que o personagem escreve no decorrer da obra, podemos sugerir alguns desses dilemas:

Talvez se eu quebrasse os cálices

derrubasse a cristaleira e

os livros da estante talvez

se eu abrisse todas as torneiras

ligasse as luzes da sala inteira

e cantasse sem afinação e

dançasse sem roupa nem ritmo

uma dança quase parada

quase indecente e largasse

meus demônios (os quatro)

e soltasse meus bichos (os muitos)

e inventasse palavras que

talvez dessem conta do buraco

talvez

se eu descartasse a higiene

deixasse a crescer a barba

permitisse o desgrenhado

dos cabelos e abrisse o

sorriso a qualquer hora

sem motivo aparente nem

pretensão de talvez pretender

um sorriso de volta

\footnotetext{
${ }^{4}$ De acordo com o autor, em seu livro que trata do amor na modernidade líquida, o homem em tempos atuais está num movimento constante e cíclico de afastamentos e aproximações com o outro, ou seja, ao passo que busca incessantemente estar acompanhado e aproveitar os limites dos prazeres, se afasta e se apoia na solidão como mecanismo de defesa.
} 
de qualquer gente

(EL-JAICK, 2009, p.48)

O aspecto a ser observado é um desejo revelado de fugir das linhas convencionais de comportamento, de irromper num surto de atitudes desvairadas que libertariam a essência do homem que está solitário, desorientado pelo que o cerca e tem a necessidade pungente de reagir a isso desobedecendo às convenções de higiene, mídia, relações interpessoais, etc. Essa vivência que sugere um desespero enclausurado assegura que, assim como afirma o próprio personagem, ele se debate com o que é, vive na angústia da solidão em meio a muitos.

Diante disso, Fátima, a cadela que mora com Henrique, revela-nos de modo nítido a personalidade de seu dono, pois, como ele mesmo a descreve: "adora cigarro, pira com fumaça de maconha e não torce o nariz para nenhuma bebida alcóolica” (EL-JAICK, 2009, p. 07), ou seja, a cadela e seus hábitos e gostos peculiares a um animal revela o dia a dia de seu dono, que é certamente habituado às drogas e bebidas como forma de desligar-se da habitual solidão do apartamento. O seguinte trecho revela a convergência de sentimentos entre Henrique e Fátima:

Na sala, Rui nos enrola um baseado, com Fátima rodando à sua volta. Túlio a suspende, coloca-a no colo. Ela se deita para receber o carinho. Olho para ela com a culpa antecipada por deixa-la sozinha nesta madrugada. Ela parece antever minha saída, encara-me como se dissesse: "Você me troca por qualquer coisa". Onde eu estava com a cabeça quando decidi comprar uma cachorra? Na época, não sabia que minhas necessidades de companhia seriam menores que as necessidades dela (EL-JAICK, 2009, p. 12).

Por isso, é possível afirmar a necessidade latente de companhia de Henrique (sendo este o motivo para ele comprar uma cadela). Entretanto, sua solidão é possivelmente desfeita nas inúmeras possibilidades que a noite e suas baladas e ruas cheias delibera. De todo modo, a noite seria substituída por um alguém que o personagem idealiza em um momento de delírio em vistas ao uso de maconha, alguém este que Henrique inventa

[...] cuja presença é em si um conforto, um alguém para sempre, sem rosto, sem passado, sem profissão, um alguém que transcende o mundano, que garante a fuga afinal da instabilidade, um alguém de contos de fadas, aquele com o qual sonhamos na infância, o ombro ao alcance da cabeça exausta, a mão ao alcance da nossa procura, o olhar contemplativo atento a nossas idiossincrasias (EL-JAICK, 2009, p. 15). 
Nessa idealização, Henrique mostra que, mesmo estando imerso na instabilidade das relações sem compromisso, na desregra da noite como jogo de busca ao prazer e no consumo do sexo; mesmo em meio ao tédio que este ato pode causar, há em sua constituição humana a incessante busca por um complemento estável, por uma relação afetiva que solidifica a monotonia tornando-a agradável e aconchegante. A emergência de formular uma fantasia que remete à infância, o sonho do parceiro perfeito, do "ombro ao alcance da cabeça exausta" revela um sujeito homossexual atravessado pela liquidez dos amores contemporâneos que, todavia, anseia ainda pela estabilidade afetiva como sendo uma forma possível de aquietar as demais mazelas da vida (BAUMAN, 2004).

Henrique sente-se sempre inseguro e segundo o que diz "Dez anos de análise me fizeram apenas entender que "essa insegurança vem da relação com seu pai", mas não me deram o antídoto que sequer se assemelhasse a uma cura" (EL-JAICK, 2009, p. 33), isto é, em face de uma relação instável, conturbada, ou inexistente com seu pai, Henrique não desenvolveu em sua personalidade firmeza para as demais relações. A ausência da figura paterna constitui para Henrique a causa de sua carência afetiva e da necessidade de fugir da realidade pungente.

Essa insegurança reflete-se também na ideia fatalista que tem sobre as pessoas (homens) com quem ele pode se relacionar. Henrique concebe que "Bíceps arredondados dão em árvore" (EL-JAICK, 2009, p. 35). Assim, os relacionamentos pretendidos (ou idealizados) pelo personagem são alicerçados sempre na forma física do outro, e nesta sociedade que elabora discursos sobre ser malhado e ter músculos torneados (em clara retomada do ideal grego de beleza) a conquista é quase um mercado, uma colheita, de pessoas e corpos iguais que de tão similares são metaforizados como frutas que estão ao alcance de quem as deseja nas suas respectivas árvores.

Nesse sentido, é possível perceber um dos aspectos dos quais Hall (2005) trata ao discutir uma identidade descentrada na contemporaneidade, pois, ao passo que o homem atual está a busca de um ter exagerado de coisas, ele mesmo se tornou coisa construível, uma máquina a ser vendida, comprada, trocada. Henrique, então, frente ao mundo que oferta corpos construídos, revela o mercantilismo humano que identidade contemporânea promove.

Assim, os pensamentos do personagem nos levam a perceber sua solidão acentuada pela segurança pretendida, isto é, estar só é uma forma de achar-se seguro. Isso é visível quando ele reflete sobre sua vida em um apartamento com sua cadela: "Penso em nós dois, trancafiados no aconchego do apartamento, quase uma trincheira de onde enfrentamos o mundo. Nossa bolha particular, nossa solidão almejada, o conforto previsível" (EL-JAICK, 2009, p. 66). No lugar isolado, a bolha particular, reside talvez a figura paterna, a relação afetiva firme, a lembrança reconfortante de que no mundo injusto e escroto que ele vislumbra existem pontos fixos onde se pode agarrar. Por meio desses pensamentos, a angústia surge, afinal a realidade o perturba. E, é na bebida, nas drogas, que Henrique busca a fuga desta realidade através de "Uma bebida que aniquile toda a consciência [...]" (EL-JAICK, 2009, p. 67). Durante a noite, então, abre-se um leque de possibilidades para romper com "[...] as carências do corpo, quem sabe da alma [...]" (EL-JAICK, 2009, p. 67). 
Henrique traça aquilo que lhe constitui: problemas psicológicos, um regime de cuidado físico com vistas à manutenção de uma pretensa beleza, um mundo em torno de seu apartamento bagunçado, mas conservado; gostos exóticos por objetos culturais, e acima de tudo um coração afligido por um relacionamento mal resolvido que lhe atravessa até hoje as memórias e quaisquer tentativas de "ir a frente". Em vistas a esses adjetivos e predicados de si, Henrique vive aquilo que a noite lhe oferece: o agora. Nessa lógica, Resende (2008) traz considerações sobre a narrativa contemporânea ser extremamente presentificada, isto é, é traço da literatura produzida sobre e pelo homem contemporâneo essa urgência do acontecimento agora, da realização iminente do ato para além da precaução. É no agora que, em suma, se realiza a vida e a transcendência está localizada no prazer dessa experiência.

Esse agora está nos diálogos, nas relações, nas transas, nas pessoas-mercadorias que a vitrine do mundo lhe oferece. Os encontros sexuais são uma forma de suprir o vazio da existência e a insegurança que é moldada pela figura forjada do Henrique-Super. Ele então, no ato sexual, pensa: "Nada no homem me repele, nada me faz querê-lo para além desta madrugada.” (EL-JAICK, 2009, p. 106). O homem, segundo a concepção der Henrique, é uma mercadoria descartável. Os corpos são o presente da relação, corpos sem história, sem nome muitas vezes, apenas com traços e formatos de músculos e órgãos que servem ao imediato agora do prazer. E nestas relações, segundo o personagem, não há “[...] Nenhuma filantropia aqui”" (EL-JAICK, 2009, p. 108), isto é, o momento e o toque são a moeda da troca imediata dos desejos e não uma forma de compra para a posteridade. A vitrine desse mundo, então, é de produtos a serem, logo que usados, descartados.

No ato sexual, existe a plena segurança aliançada à indiferença. Segundo Henrique, naquele momento de sexo em uma sauna, "Não penso em nada. Estou alheio ao mundo lá fora, estou alheio ao que se passa aqui dentro. [...]” (EL-JAICK, 2009, p. 110). Nesse sentido, o agora das satisfações instantâneas é também um momento de total desligamento dos sentidos de consciência. Não existe, pois, no sexo nada de reflexão ou crítica, é somente um ato de utilização, é usufruir daquilo que foi comprado. Talvez, então, por viver estas indiferenças em contraponto à consciência do mundo-lá-fora e de si, Henrique sinta-se, muitas vezes, invisível.

\section{Da anatomia do erotismo sob o olhar da rua}


No que diz respeito a uma postura social, frente à crítica de si, ao auto olhar de julgo, Henrique constitui-se também da observação dos sujeitos de fora. Nesse sentido, El-Jaick (2009) caracteriza um homem homossexual prestes a sair às ruas em busca de diversão, mas que, em seu íntimo, pressente e teme o olhar do outro-avaliador, da sociedade que quantifica e qualifica os corpos numa pretensa busca de perfeição padronizada. Henrique, então, sente “[...] a iminência de me encontrar à mercê da avaliação alheia, essa punheta [...]” (EL-JAICK, 2009, p. 09), porém busca ignorar este sentimento sabendo que a noite pela qual ele certamente se embrenhará é um jogo de olhos atentos aos corpos escupíveis e aos desleixos reprováveis.

Assim, frente aos padrões estéticos na sociedade contemporânea, Henrique demonstrase como sendo "liberal", mesmo que de si busque sempre um julgamento da aparência que logo em seguida releva e isso possivelmente faz ponte com o processo aludido por Hall (2005) que se trata da diferenciação - a experiência de um eu individual frente ao coletivo -, pois o personagem-narrador tem o outro e sua forma de olhar para ele como parâmetros de sua própria constituição individual.

Percebemos, também, esse olhar ao estético e sua visão de liberdade quando o mesmo diz: "Penso nas pernas peludas dos caras da academia, a penugem revestindo a pele. Viva a diversidade" (EL-JAICK, 200, p. 19). O sujeito Henrique observa de maneira não preconceituosa as formações diversas do estético em nossa sociedade. Nesse sentido, é possível afirmarmos que ele se constitui em meio às exigências do padrão de beleza ${ }^{5}$ formulado nas mídias e discursos da contemporaneidade, entretanto ignora-o e isto acarreta pensarmos os diversos níveis de massificação dos gostos estéticos que na obra são debatidos na figura do urso em diálogo entre Henrique e seus amigos.

A visão de que "[...] "urso" virou uma designação para tudo que foge ao esteticamente agradável." (EL-JAICK, 200, p. 19) nos faz conceber a importância que a aparência toma na narrativa e na constituição do sujeito homossexual na obra tendo em vista a forma como os “tipos de gay” (Barbie, Urso, Megera ${ }^{6}$ ) são representados e discursivizados. O estético e a

\footnotetext{
${ }^{5}$ Esse detalhe é abordado por Foucault (2015) no que diz respeito à atrelação do corpo (e seu domínio clínico) com as relações interpessoais. Forjou-se por tempos uma transcendência das relações, um amor romântico a ser alcançado, que agora se liquefaz (Bauman, 2004) ao passo que o homem é constituído na esfera clínica como mercadoria posta à venda numa loja que exige qualidade ímpar aos seus produtos.

${ }^{6}$ Esses "tipos de gay" fazem parte de um imaginário social que classifica as personalidades homossexuais segundo trejeitos, senso estético e - por vezes - segundo as preferências sexuais. Desse modo, a barbie seria o homossexual que traz consigo o apelo estético das academias e "forçaria" a masculinidade pelo corpo como referencial de saúde e beleza; o urso seria o oposto da barbie, pois esse homossexual não estaria atrelado ao estético relacionado às academias e ao apelo da mídia, isto é, seria o gay que é gordo, peludo e geralmente com mais de 40 anos de idade;
} 
aparência tomam, então, caráter identitário, isto é, uma identidade homossexual passaria também pela forma de se vestir, hábitos de saúde e beleza, modos de falar e até mesmo técnicas de sedução. O estereótipo do homossexual como sendo fissurado por musculação, depilação, beleza, baladas, filmes pornográficos, sexo casual, empreende a idealização deste sujeito frente à extrema sexualidade e imagem em padrões estéticos que aludem ao pensamento grego de beleza. (TREVISAN, 2009).

Na obra, ainda, Henrique é figurado enquanto personagem humano que vê e tem consciência dos males que a sociedade carrega e não somente como sujeito sexual. É, pois, do sujeito social (socializado) perceber como funciona e é regida a máquina estrutural do país. Nesse ponto, há concordância entre o que Candido (1995) afirma: a relação intrínseca entre o que é literarizado e a sociedade na e pela qual acontece a necessidade de representação de uma experiência humana, tal como a pobreza, a homossexualidade, etc. Desse modo, o seguinte trecho nos revela esta possível consciência, eximida de ação ou alteração:

Paramos no sinal, surgem três meninos de rua, e fecho automaticamente o vidro. Eles passam por nós sem nenhum interesse, sentam-se na calçada para comer o que parecem ser salgados enrolados num papel gorduroso. É inevitável o sentimento de culpa que me invade.

- Ser brasileiro é segurar o cu com uma mão e dar a outra à palmatória murmuro.

(EL-JAICK, 2009, p. 23)

A culpa sentida pelo personagem demonstra que de alguma forma comove-o saber da impotência que lhe transpassa e impede de mudar o caos social que o cerca, dentro do qual a fome, a miséria das ruas e a infância ceifada estão inseridas. A metáfora utilizada por Henrique para definir a identidade nacional reverbera de modo cru a consciência de que em nosso país estamos atados por um lado ao medo e por outro à punição. Sua atitude de fechar o vidro do carro frente à presença dos meninos moradores de rua revela que, mesmo sendo sujeito ciente desses males, ele teme as figuras que estão inseridas no ciclo de pobreza e miséria. A culpa que o atravessa possivelmente é resultado da impotência, mas também da consciência de uma covardia acentuada frente à situação que ele vivenciou.

a megera é o homossexual que segundo o imaginário social tem por característica principal o mau humor, o humor felino e dizeres e atitudes chamadas venenosas, ou seja, seria o gay que encarna a figura do sujeito "mal amado". 
Diante de tais mazelas, Henrique constitui-se ainda sujeito pela fuga possível deste mundo de desgraças com o auxílio de entorpecentes. A felicidade para o personagem é definida da seguinte maneira: “O corpo semianestesiado pelo álcool, a cabeça leve: minha ideia definitiva de felicidade” (EL-JAICK, 2009, p. 24). A felicidade é, pois, a fuga, a eximição de ver, de sentir em verdade as crueldades e males do mundo contemporâneo. Fechar a janela do carro, drogar-se, ignorar a culpa, o estético que lhe atravessa, mas não acrescenta, são provas de que Henrique é enlaçado pela consciência insistente do seu mundo em redor, mas a ação de transformação (a mudança de estado) lhe frustra.

Enquanto sujeito, Henrique é constituído pela esfera de sua sexualidade, mesmo que o mesmo busque a estabilidade inatingível; busca ainda eximir-se das culpas do estético e da sociedade de miséria que o atravessam. Nesse universo gay, Henrique também percebe o medo que ronda as relações homoafetivas, tendo em vista que ele afirma:

Penso nas trepadas com metragem de segurança. Até aqui, tudo bem. Até aqui, tudo bem. A escalada do risco: da abstinência ao sexo anal desprotegido, passando pelo terreno acidentado do sexo oral. E beijo de língua, pode? E se houver afta na boca, pode? Talvez uma nota 4 para o risco de infecção, é pegar ou largar. Penso na presença constante da consciência do perigo rondando a cama (EL-JAICK, 2009, p. 41).

Em meio aos perigos das Infecções Sexualmente Transmissíveis (IST), as relações sexuais tornam-se um ambiente de risco, um jogo duro entre a excitação, o prazer, a satisfação e o gozo em detrimento da doença, a infecção e a iminente morte. A cama, lugar onde se realiza a natureza do sexo enquanto ato biológico de satisfação mútua, torna-se a arena deste jogo. Ronda, assim, sinuosamente, a linha entre o risco e êxtase. E é neste mundo de riscos, de corpos que dão em árvore que Henrique entende que "Liberdade não existe, é um conceito vazio" (ELJAICK, p. 47). Esta pretensa liberdade que talvez existisse nas festas, na bebida, na sexualidade exposta e exacerbada, não se concretiza, pois, o homem é um eterno enclausurado e as prisões se multiplicam, a exemplo da solidão, do tédio, da melancolia vivida por Henrique em meio às multidões que ele visita.

É ainda neste mundo real que é "uma merda" (EL-JAICK, 2009, p. 50) que Henrique vive. Por isso ele deseja guardar seu amigo Rui para “[...] poupá-lo da escrotidão do mundo, nenhum telejornal para o meu amigo, nenhuma volta pela cidade injusta, o cartão-postal da miséria, quero guarda-lo num casulo, longe do real" (EL-JAICK, 2009, p. 50). Nesse desejo, o 
personagem expressa sua visão do mundo que é "escroto", "injusto" e que midiatiza e prolifera as misérias. A cidade é, pois, um mosaico nítido de coisas (objetos, pessoas, sentimentos, ausências) como que em um mercado. Este lugar é compreendido por Henrique na metáfora de “[...] grande queima de estoque, como mercadorias irresistíveis ao alcance da mão" (EL-JAICK, 2009 , p. 55).

Assim, é na experiência da noite desregrada que Henrique busca sufocar as suas inseguranças e a consciência do mundo cruel que vende, em vitrines amplas, as pessoas como coisas ao passo que expõe e prolifera a miséria e midiatiza as desgraças. Para sobreviver a esta noite, é preciso ainda atuar de modo perfeito, forjar um eu fora do melancólico, solitário e malamado. A identificação, pois, é quase uma forma de atuar e isso remete ao que Rose (2001) chama de a transitoriedade das identidades, tendo em vista que não se concebe mais o ser como linear em sua performance social, mas como móvel diante das instâncias e situações. O sujeito é um conglomerado de identidades que protagonizam-se de acordo com a experiência de agora do sujeito.

Assim, afirma Henrique, “Aos poucos, encarno o bom ator que sou, minha farsa secreta digna de Oscar, aplausos da crítica e fã-clubes. O bom ator apesar da sobriedade - Eu sou supertranquilo. Superbacana. Superjovem. Superdescolado, a imagem leve que fazemos questão de vender, prefixo dizendo mais do que a própria raiz" (EL-JAICK, 2009, p. 72). O personagem reforça a ideia que tem do mundo, das relações e de si: um produto a ser vendido, leiloado, que necessita expor os benefícios (prefixos) sem de modo algum transparecer as raízes (os defeitos). Deste modo, em um sistema de mercado, propagam-se as imagens agradáveis, os traços vantajosos, forjam-se os caracteres das coisas e das pessoas a fim de alcançar o lucro, a venda, o movimento do câmbio.

Em meio a esta vida forjada às vitrines, afora dos prefixos criados para vender, Henrique se autodescreve como produto no qual

O que está à venda: uma cabeça assombrada de complicações, um corpo mantido em sua melhor forma a alto custo, um apartamento com vista para outros apartamentos, uma cadela de carência inesgotável, um laptop cuja tela deu pau e agora precisa de monitor externo, uma cama de casal com o lado esquerdo do colchão mais gasto do que o direito, uma coleção eclética de CDs, DVDs e livros, uma tela de Hopper, um guarda-roupa que parece sempre defasado. Uma geladeira com produtos contraditórios. Uma rua esparsamente arborizada, sem ladrilhos de brilhante. Um carro em bom estado, com IPVA em dia. Um coração sobre o qual o inquilino esqueceu de botar a placa PASSO 
O PONTO. O que está ao alcance dos olhos e o que lhes escapa. Vende-se um pedaço de história, alguns anos com promessa de décadas (EL-JAICK, 2009, p. 83).

Por isso, ao dar-se conta de um jovem rapaz homossexual, Henrique pensa em alertá-lo sobre a vida que o aguarda: "E, num ímpeto de crueldade, quero informar ao menino muito jovem que nada tapará esse buraco, apenas matéria própria do terreno da fantasia, nunca migalhas da realidade, nunca um beijo, um amasso, uma foda" (EL-JAICK, 2009, p. 130).

Nesse sentido, o personagem compreende que a noite e suas possibilidades de sexo, bebidas, drogas e êxtase do corpo ainda não é suficiente para sanar as mazelas da alma, os traços traumáticos do psicológico. A alma, então, não consegue ser suprida daquilo que perdeu com nada que a vitrine do mundo possa expor e oferecer à venda. A busca do preenchimento do vazio interior é, assim, inútil.

Desta maneira, Henrique conclui que "Somos fáceis, gratuitos, entregues, a carne exposta, a calça arriada em torno dos joelhos, a camisa erguida acima do peito, as mãos ávidas, o suor comunitário, a comunhão quase sacra: "um nojo", eu talvez dissesse se estivesse menos bêbado, se sentisse menos tesão, se fosse uma pessoa mais pudica" (EL-JAICK, 2009, p. 131132). Para o personagem, a iminência do corpo alheio dado aos nossos desejos imediatos de sexo nos torna fáceis. O vazio, então, é mais que uma metáfora da gama dos sentimentos humanos, mas sim a descrição literal dos próprios indivíduos.

Permeia na a constituição de Henrique dois traços peculiares do sujeito contemporâneo: 1 - a possibilidade de ser alguém de acordo com o lugar, hora, situação, isto é, uma das diversas formas das identidades possíveis na contemporaneidade, as quais são móveis, é representada em Henrique no sentido de que o mesmo vive situações em que atua - dignas de Oscar, segundo sua narrativa - e esconde sua "verdadeira vida". Essa possibilidade de ser muitos em um só homem é característica de um sujeito que se descentrou e da liquidez das relações contemporâneas e isso se apresenta de modo claro em Henrique pela angústia vivenciada no íntimo da casa, a solidão frente à pornografia, os temores relacionados às IST, os entorpecentes e o álcool como formas de modificar as sensações negativas, o que não se dá totalmente; 2 essa solidão em meio às multidões que é revelada na experiência psicológica e física de Henrique também é traço atestado dos sujeitos contemporâneos, tendo em vista que, de acordo com Bauman (2004), a maioria das relações interpessoais atuais estão no campo da necessidade 
de atenção sem um verdadeiro compromisso com durabilidade. A solidão é consequência da extrema transitividade dos sujeitos.

Finalmente, podemos sugerir quem é Henrique e sua identidade homoerótica: um sujeito atravessado pela experiência sexual desregrada e tratada como meio de escape de uma solidão que, ainda que revelada na forma como pensa e sente o personagem, é maquiada com trejeitos de felicidade e atividades cotidianas como festas e orgias (as quais sugerem felicidade). $\mathrm{O}$ homoerotismo transparece na experiência de Henrique para percebermos as diversas formas líquidas e instáveis de se relacionar, de experiências a modernidade como entorpecentes, o sexo beirando sempre o limite entre o prazer e o risco de vida, os amores e os males psicológicos que o excesso possivelmente acarreta. É na solidão entre os milhares que a sexualidade de Henrique e suas diversas práticas sexuais emergem como tentativa de acabar com o "buraco", mesmo que ao fim de uma noite de experiências de prazer, esse sentimento se esvai e todo o vazio retorna, ou, em última sugestão, ele jamais tenha deixado de existir.

\section{CONSIDERAÇÕES FINAIS}

No presente trabalho, objetivamos analisar como se constitui a identidade homoerótica do personagem-narrador Henrique na obra literária contemporânea Anatomia da Noite (2009) de Márcio El-Jaick. Para isso, discutimos inicialmente os conceitos de identidade, identificação e diferenciação, percebendo que os três conceitos se interdependem e se correlacionam. Além disso, tratamos do descentramento da identidade no pós-modernismo e as diversas formas de se pensar o processo de constituição do sujeito.

Logo após, tratamos dos meios pelos quais se enxergou (ou enxerga) o sujeito homossexual no Ocidente, especificamente no Brasil. Discutimos, assim, as diversas relações que esses sujeitos e sua sexualidade desempenham na formação das imagens sobre eles, bem como retratamos um breve traçado histórico dessas imagens, contrapondo os mecanismos sociais que os constituíram na teia da história.

Finalmente, através dessas teorias, analisamos na obra de El-Jaick os diversos traços psicológicos e sociais do personagem a fim de demonstrar como se constitui na mesma a experiência homoerótica e assim a identidade alinhada a essa mesma experiência. Considerando, pois, os traços de solidão e desregramento da personalidade de Henrique, 
compreendemos que o mesmo é um sujeito que utiliza sua sexualidade e o sexo como meio de sanar sua solidão e as mazelas psicológicas que o atravessam desde a infância.

A anatomia demonstrada revela-se em dois ambientes: a casa e a rua, muitas vezes diferenciadas pela atuação do personagem em cada um desses ambientes. É possível afirmar que são expostos dois Henriques, os quais se alternam psicologicamente e fisicamente nas situações em que são requeridos. O sexo conclama um, descolado, jovial e erotizado; já o ambiente interno da casa, conclama o solitário, o que em sua estrutura psicológica vive sob extrema monotonia e desânimo. Dois sujeitos bem opostos ocupando o mesmo corpo.

Finalmente, há pontos que o presente estudo, em decorrência de limites de tempo e espaço, não pode comportar, tais como as relações paternais e conjugais reveladas por Henrique, bem como sua maneira de relacionar-se com o sexo casual e a mentalidade de que isso seria uma forma de mercado das pessoas, além das relações apresentadas por Henrique no que diz respeito à estética contemporânea dos corpos aceitáveis e os preconceitos enfrentados por homossexuais. Esses pontos são inquietações que permanecem para outras pesquisas que possivelmente virão.

\section{REFERÊNCIAS}

BAUMAN, Z. Identidade: entrevista a Benedetto Vecchi. Rio de Janeiro: Jorge Zahar Ed., 2005.

BAUMAN, Z. Amor líquido: sobre a fragilidade dos laços humanos. Rio de Janeiro: Jorge Zahar Ed, 2004.

CANDIDO, A. O direito à literatura. In: Vários escritos. 3. ed. São Paulo: Duas Cidades, 1995.

EL-JAICK, M. Anatomia da noite. São Paulo: GLS, 2009.

FOUCAULT, M. O sujeito e o poder. In: DREYFUS, H.; RABINOW, P. Michel Foucault, uma trajetória filosófica. Rio de Janeiro: Forense Universitária, 1995.

FOUCAULT, M. A história da sexualidade 1: a vontade de saber. 2 Ed. São Paulo: Paz e Terra, 2015.

HALL, S. A identidade cultural na pós-modernidade. Tradução de Tadeu da Silva e Guacira Lopes Louro. 10. Ed. Rio de Janeiro: DP\&A, 2005.

ROSE, N. Inventando nossos eus. In: SILVA, Tomaz Tadeu da. (Org.). Nunca fomos humanos: nos rastros do sujeito. Belo Horizonte: Autêntica, 2001. 
RESENDE, B. Contemporâneos: expressões da literatura brasileira no século XXI. Rio de Janeiro: Casa da Palavra, 2008.

SILVA, T. T. A produção social da identidade e da diferença. In: SILVA, T. T. Identidade e diferença: a perspectiva dos estudos culturais. Rio de Janeiro: Vozes, 2013.

TREVISAN, J. S. Devassos no paraíso: a homossexualidade no Brasil, da colônia à atualidade. 3 Ed. São Paulo: Record, 1995. 